\title{
Genetic diversity and its conservation implications of Vitex rotundifolia (Lamiaceae) populations in East Asia
}

Yiqi Sun ${ }^{1}$, Hong Yang ${ }^{2}$, Qiaoyan Zhang ${ }^{3}$, Min Jia ${ }^{\text {Corresp., }}{ }^{3}$, Pan Li ${ }^{4}$, Joongku Lee ${ }^{5}$, Shichao Chen ${ }^{6}$, Khalid Rahman ${ }^{7}$, Tingguo Kang ${ }^{\text {Corresp.. }}{ }^{1}$, Luping Qin ${ }^{3,8}$

${ }^{1}$ College of Pharmacy, Liaoning University of Traditional Chinese Medicine, Dalian, Dalian, Liaoning, China

2 School of Medicine, Tongji University, Shanghai, China

3 Department of Pharmacognosy, Second Military Medical University School of Pharmacy, Shanghai, China

4 Key Laboratory of Conservation Biology for Endangered Wildlife of the Ministry of Education, and Laboratory of Systematic \& Evolutionary Botany and Biodiversity, College of Life Sciences, Zhejiang University, Hangzhou, Zhejiang, China

5 Department of Environment and Forest Resources, College of Agriculture \& Life Sciences, Chungnam National University, Daejeon, South Korea

6 College of Life Science and Technology, Tongji University, Shanghai, China

7 School of Pharmacy and Biomolecular Sciences, Liverpool John Moores University, Liverpool, United Kingdom

8 College of Pharmaceutical Sciences, Zhejiang Chinese Medical University, Hangzhou, Zhejiang, China

Corresponding Authors: Min Jia, Tingguo Kang

Email address: jm7.1@163.com, kangtingguo@163.com

Vitex rotund ifolia is an important coastal and medicinal plant, and is recorded in the List of the Important Wild Plants for Conservation in China and Japan. However, an effective conservation strategy is lacking. In the present study, the genetic diversity and population structure were analyzed using phylogeographical methods based on the trnH-psbA and trnG-trnS intergenic spacers of the chloroplast DNA (cpDNA) sequences from 157 individuals from 25 sampling sites for $V$. rotundifolia and $V$. trifolia plus the internal transcribed spacer (ITS) of the nuclear ribosomal DNA (nrDNA) sequences of 177 individ uals from 27 sampling sites. The results showed that $V$. rotundifolia and $V$. trifolia had eight cpDNA and two nrDNA haplotypes, respectively, and the $V$. rotundifolia has a low level of genetic diversity (haplotype diversity $\left(h_{d}\right)_{, c p}=0.360, h_{d, n r}=0.440$ ), a more pronounced genetic differentiation among populations (population differentiation at the species level $\left(\mathrm{G}_{\mathrm{ST}}\right)=0.201$, population differentiation at the allele level $\left.\left(\mathrm{N}_{\mathrm{ST}}\right)=0.462\right)$, and an insignificantly different phylogeographical structure $\left(\mathrm{N}_{\mathrm{ST}}>\mathrm{G}_{\mathrm{ST}}, P>0.05\right)$. In addition, haplotype network analyses indicated that $V$. rotundifolia and $V$. trifolia have distinct haplotypes. Divergence dating based on BEAST software analyses showed that most cpDNA clades diverged in the late Pleistocene era. Demographic analysis indicated that $V$. rotundifolia underwent a rapid demographic expansion. Some scientific strategies are suggested for resource conservation of $V$. rotundifolia based on its genetic diversity and population structure. 


\section{Genetic diversity and its conservation implications of Vitex rotundifolia}

\section{2 (Lamiaceae) populations in East Asia}

3 Yiqi Sun ${ }^{1} \uparrow$, HongYang ${ }^{3} \uparrow$, Qiaoyan Zhang ${ }^{2}$, Min $\mathrm{Jia}^{4}$, Pan $\mathrm{Li}^{5}$, Joongku Lee ${ }^{6}$, Shichao Chen ${ }^{7}$,

4 Khalid Rahman ${ }^{8}$, Tingguo Kang ${ }^{1}$, Luping Qin ${ }^{2,4}$

5 1. College of Pharmacy, Liaoning University of Traditional Chinese Medicine, Dalian 116600,

6 China.

7 2. College of Pharmaceutical Sciences, Zhejiang Chinese Medical University, Hangzhou 8311402 , China.

9 3. School of Medicine, Tongji University, Shanghai 200092, China.

4. Department of Pharmacognosy, Second Military Medical University School of Pharmacy, Shanghai 200433, China

†Yiqi Sun and HongYang contributed equally to this work 


\section{Abstract}

Vitex rotundifolia is an important coastal and medicinal plant, and is recorded in the List of the Important Wild Plants for Conservation in China and Japan. However, an effective conservation strategy is lacking. In the present study, the genetic diversity and population structure were analyzed using phylogeographical methods based on the trnH-psbA and trnG-trnS intergenic spacers of the chloroplast DNA (cpDNA) sequences from 157 individuals from 25 sampling sites for $V$. rotundifolia and $V$. trifolia plus the internal transcribed spacer (ITS) of the nuclear ribosomal DNA (nrDNA) sequences of 177 individuals from 27 sampling sites. The results showed that $V$. rotundifolia and $V$. trifolia had eight cpDNA and two nrDNA haplotypes, respectively, and the $V$. rotundifolia has a low level of genetic diversity (haplotype diversity $\left(\mathrm{h}_{\mathrm{d}}\right)$, $\left.\mathrm{cp}=0.360, \mathrm{~h}_{\mathrm{d}, \mathrm{nr}}=0.440\right)$, a more pronounced genetic differentiation among populations (population differentiation at the species level $\left(\mathrm{G}_{\mathrm{ST}}\right)=0.201$, population differentiation at the allele level $\left.\left(\mathrm{N}_{\mathrm{ST}}\right)=0.462\right)$, and an insignificantly different phylogeographical structure $\left(\mathrm{N}_{\mathrm{ST}}>\right.$ $\left.\mathrm{G}_{\mathrm{ST}}, P>0.05\right)$. In addition, haplotype network analyses indicated that $V$. rotundifolia and $V$. trifolia have distinct haplotypes. Divergence dating based on BEAST software analyses showed that most cpDNA clades diverged in the late Pleistocene era. Demographic analysis indicated that $V$. rotundifolia underwent a rapid demographic expansion. Some scientific strategies are suggested for resource conservation of $V$. rotundifolia based on its genetic diversity and population structure. 
47

48

49

50

51

52

\section{Introduction}

Vitex rotundifolia, which often grows on beaches and sand dunes, is a widely distributed shoreline shrub of the family Lamiaceae, (Cantino, 1992; Harley, 2004; Cousins et al., 2010). V. rotundifolia plays an important ecological role in stabilizing sand dunes in coastal areas (Gresham \& Neal, 2004; Kim, 2005). In addition, the fruit of $V$. rotundifolia, known as Manjingzi, is a herbal medicine commonly used in China and Japan to prevent and treat colds, headache, and migraine (Sung et al., 1996). However, the increased use of the plant as a medical resource, coastal overexploitation, and environmental destruction, have accelerated the degradation of $V$. rotundifolia populations, decreased the intraspecific variation, severely destroyed its natural habitats, and even threatened the survival of the species. Given the vulnerability of $V$. rotundifolia, it has been recorded in the List of the Important Wild Plants for Conservation in China and Japan (http://www. cites.org. cn/article/show.php?itemid=589; Ohtsuki et al., 2014). Therefore, it is necessary to provide an effective conservation strategy for this species.

Based on a comprehensive allozyme study of $V$. rotundifolia Korean populations, Yeeh et al. (1996) reported that the levels of genetic variation and differentiation within populations are considerably lower, but are higher among populations. By contrast, levels of genotypic diversity within and among populations were moderate. They indicated that clonal reproduction might act as an enhancer of genetic drift by reducing the effective size of local $V$. rotundifolia populations. Ohtsuki et al. (2014) developed ten microsatellite makers from V. rotundifolia Japanese populations; however, no further data were presented. Hu et al. (2008) investigated the genetic variation of $V$. rotundifolia at more extensive sampling areas in Chinese populations using inter simple sequence repeat (ISSR) markers. Their fine-scale spatial autocorrelation analysis showed a clear within-population structure, with gene clusters of approximately $20 \mathrm{~m}$, which could act as a guide for sampling strategies. They also reported the overall genetic diversity (GD) of $V$. rotundifolia on China was moderate $(\mathrm{GD}=0.190)$ and the genotypic diversity was greater than the average values for a clonal plant, indicating its significant reproduction through seedlings. 
Pharmacological research discovered that the genetic variation pattern was closely associated with the chemical constituents in the fruit of $V$. rotundifolia (Hu et al., 2007). Currently, our understanding of the genetic variation background of this species is poor, especially concerning the population genetic structure and phylogeography. In addition, we lack specific advice for the conservation of $V$. rotundifolia.

$V$. trifolia is another important medicinal plant and is the closest relative of $V$. rotundifolia. $V$. trifolia is only distributed in a very narrow area in Southwest of China and Taiwan province, and the independent species taxonomic status between $V$. trifolia and $V$. rotundifolia has long been disputed (Munir, 1987; Kok, 2007, 2008; Barger et al., 2012; Chang, Kim, \& Chang, 2014; Franck et al., 2016). The fruit of $V$. trifolia have also been recorded in the Pharmacopoeia of China as Manjingzi (Editorial Committee of Chinese Pharmacopoeia, 2015) for medical use. Therefore, the addition of $V$. trifolia in this study could help to analyze the evolutionary history of $V$. rotundifolia and to better understand their genetic differentiation.

The analyses of population genetic structures, genetic variations across populations, and the geographical distributions of the species at risk of extinction will help to develop appropriate conservation decisions and sustainable utilization strategies (Millar \& Libby, 1991). Phylogeographical methods are often used to assess the variability of molecular markers within a taxon across both time and space, to deduce the historical processes that may have been responsible for the contemporary geographical distributions of individuals and population genetic structures, and help to prioritize areas of high value for conservation (Avise \& John, 2000; Franck et al., 2016; Kumar \& Kumar, 2018). Chloroplast DNA (cpDNA), which is maternally inherited in most angiosperm plants, is commonly considered as a single nonrecombinant unit of inheritance and often is used to investigate the phylogeographical processes associated with seed dispersal, such as range expansion (Clegg et al., 1994; Petit et al., 1997). Nuclear ribosomal DNA (nrDNA), which exhibits different modes of inheritance, can also be used to determine a species' genetic structure. The combination of highly conserved and variable regions allows us to make phylogenetic inferences across a wide range of evolutionary 
101 timescales and to unravel the genetic variation and demographic history of a plant species 102 (Weitemier et al., 2015).

103 In the present study, we analyzed the cpDNA and internal transcribed spacer (ITS) haplotype

104

105

106

107

108

109

110

111

112

113

114

115

116

117

118

119

120

121

122

123

124

125

126

127

sequences from 23 sampling sites covering most distribution ranges of $V$. rotundifolia in East Asia; and four sampling sites of $V$. trifolia, to explore the genetic variation pattern, population structure, and the evolutionary history of $V$. rotundifolia, with the aim of proposing effective strategies for its resource conservation.

\section{Materials and Methods}

\subsection{Population sampling}

A total of 157 individuals of $V$. rotundifolia and $V$. trifolia from 25 sampling sites for cpDNA and 177 individuals of $V$. rotundifolia and $V$. trifolia from 27 sampling sites for ITS were sampled from distribution areas in East Asia (Table 1 and Fig.1). Leaf samples were collected from individuals separated by more than $20 \mathrm{~m}$ to avoid collecting the same clones (genotypes). The leaf samples were dried in silica gel and then stored in a freezer $\left(-20{ }^{\circ} \mathrm{C}\right)$ for use. A sample of $V$. negundo from Shanghai was also collected as the outgroup. Voucher specimens were deposited in the herbarium of the Second Military Medical University (Shanghai, China).

\subsection{Sequencing of cpDNA and nrDNA}

The noncoding regions DNA sequences of cpDNA trnG (encoding tRNA glycine)-trnS (encoding tRNA serine) and trnH (encoding tRNA Histidine)-psbA (encoding photosystem II protein D1) and ITS intergenic spacer region DNA sequences were examined to analyze the genetic variation in $V$. rotundifolia and $V$. trifolia from different geographical locations (Hamilton, 1999; Shaw et al., 2007; Zhang et al., 2014). Total DNA was extracted using a HiDNA secure Plant Kit (Tiangen Biotech (Beijing) Co., Ltd, Beijing, China). PCR amplification was conducted in a total reaction volume of $50 \mu$, containing 10-20 ng total DNA, with $1 \mu$ of each primer, $21 \mu \mathrm{l}$ of $\mathrm{ddH}_{2} \mathrm{O}$, and $25 \mu \mathrm{l}$ of $2 \times$ Trans Taq High Fidelity (HiFi) PCR SuperMix (Transgen Biotech, Beijing, China). Double-stranded DNA was amplified after 3-min incubation 
128

129

130

131

132

133

134

135

136

137

138

139

140

141

142

143

144

145

146

147

148

149

150

151

152

153

154

at $94{ }^{\circ} \mathrm{C}$; followed by 30 cycles at $94{ }^{\circ} \mathrm{C}$ for $30 \mathrm{~s}, 54 / 56{ }^{\circ} \mathrm{C}$ for $30 \mathrm{~s}$, and $72{ }^{\circ} \mathrm{C}$ for $30 \mathrm{~s}$; with a final extension at $72{ }^{\circ} \mathrm{C}$ for $15 \mathrm{~min}$. To examine the geographical distribution of cpDNA and nrDNA in $V$. rotundifolia and $V$. trifolia, we amplified two noncoding regions of cpDNA trnG$\operatorname{trnS}$ and $\operatorname{trnH}-p s b A$ and ITS intergenic spacer regions using primers that successfully amplified the expected DNA fragments and exhibited some variations in our preliminary experiments (Hamilton, 1999; Shaw et al., 2007; Zhang et al., 2014). Primers used for PCR amplification were also used as sequencing primers. The PCR products were assessed using electrophoresis through $1.0 \%$ agarose gels and then used as templates for direct sequencing. Sequencing was conducted from both ends. The cpDNA and ITS sequences data of $V$. rotundifolia and $V$. trifolia samples have been submitted to the GenBank database, and the accession numbers for the trnGtrnS, trnH-psbA, and ITS sequences are MG822129-MG822287, MG822468-MG822626, and MG822288-MG822467, respectively.

\subsection{Phylogenetic analyses}

Geneious Pro V4.8.5 (http://www.geneious.com/) was used to check and align the DNA sequences. Bayesian analysis (BI) was performed on MrBayes3.1.2 to construct the phylogenetic tree of haplotypes based on the combined cpDNA data (Ronquist et al., 2012). T92+G was selected as the model for the cpDNA dataset using Modeltest version 3.06 (Posada \& Crandall, 1998) and the Akaike Information Criterion (AIC) was used to calculate the parameters and assumptions for the sequence partitions. Two runs of four simultaneous Monte Carlo Markov Chains (MCMC) analyses were performed for 10,000,000 generations, with sampling done every 100 generations. Log-likelihood values were examined for stationarity to determine the burn-in value, which was 5,000 trees in this case. TCS 1.21 (Clement, Posada \& Crandall, 2000) was applied to build a genotype network based on the $90 \%$ parsimony criteria with the option of treating gaps as a fifth base.

\subsection{Molecular dating}

The program BEAST version 1.5.3 (Drummond et al., 2012) was used to estimate the divergence times of the major lineages to the most recent common ancestor (TMRCA). Considering there 
155

156

157

158

159

160

161

162

163

164

165

166

167

168

169

170

171

172

173

174

175

176

177

178

179

180

181

are no fossil records and no specific substitution rates to calibrate the molecular clocks, the published nucleotide substitution rates were used to estimate the divergence time between two species, and a rate of about $1.2-1.7 \times 10^{-9}$ substitutions per neutral site per year $(\mathrm{s} / \mathrm{s} / \mathrm{y})$ was used to obtain absolute values of TMRCA (Eyrewalker, 2000).

\subsection{Population genetic diversity and genetic differentiation}

The program DnaSP v5.10 was used to calculate the haplotype diversity $\left(h_{d}\right)$ and nucleotide diversity $\left(\pi_{d}\right)$ based on the cpDNA and nrDNA sequences of $V$. rotundifolia and $V$. trifolia (Librado \& Rozas, 2009). To prevent an insufficient sampling affect, we re-analyzed the nucleotide diversity of $V$. rotundifolia excluding poorly sampled populations.

The analyses of molecular variance (AMOVA) in ARLEQUIN 3.5 were performed to calculate the genetic variation between $V$. rotundifolia and $V$. trifolia groups, among populations within groups, and within populations, using a significance test based on 1000 permutations (Excoffier \& Lischer, 2010). The program PermutCpSSR_1.2.1 (Pons \& Petit, 1996) was used to calculate the within-population diversity $\left(h_{\mathrm{S}}\right)$, total diversity $\left(h_{\mathrm{T}}\right)$, geographical total haplotype diversity $\left(V_{\mathrm{T}}\right)$, geographical average haplotype diversity $\left(V_{\mathrm{S}}\right)$, the level of population differentiation at the species level $\left(G_{\mathrm{ST}}\right)$, and an estimate of population subdivisions for phylogenetically ordered alleles $\left(N_{\mathrm{ST}}\right) . G_{\mathrm{ST}}$ and $N_{\mathrm{ST}}$ are often used to assess the geographical structure affecting population differentiation.

\subsection{Demographic history}

Tajima's $D$ test and Fu's $F$ s test in the ARLEQUIN 3.5 software, with 1000 permutations, were applied to detect historical demographic range expansions of $V$. rotundifolia and $V$. trifolia (Excoffier \& Lischer, 2010). The significance of the D value is associated with bottlenecks, selective effects, population expansion, or heterogeneity of mutation rates (Tanaka et al., 2011). In addition, 'mismatch distributions' analysis was performed using the DnaSP v5.10 program to detect any recent demographic expansions of $V$. rotundifolia or $V$. trifolia (Librado \& Rozas, 2009). 


\section{Results}

\subsection{Genetic diversity based on cpDNA and ITS sequences}

Based on the 157 samples of $V$. rotundifolia and $V$. trifolia individuals, the nucleotide sequence lengths were $848 \mathrm{bp}$ and $271 \mathrm{bp}$ for the $\operatorname{trn} G$-trnS and trnH-psbA regions, respectively. The combined cpDNA sequence length after multiple alignments was 1119 bp. In total, six polymorphic sites and eight haplotypes were detected, and the aligned sequence variations are summarized in Table 2 . The number of haplotypes, haplotype diversity $\left(\mathrm{h}_{\mathrm{d}}\right)$, and the nucleotide diversity $\left(\pi_{\mathrm{d}}\right)$ within each population are presented in Table 1. Finally, three haplotypes were obtained from 17 populations, plus four sites with a single sample of $V$. rotundifolia, and five haplotypes were obtained from four sampling sites of $V$. trifolia (Fig. 2). The value of haplotype diversity $\left(h_{d, ~ c p}\right)$ ranged from 0 to 0.639 , and the nucleotide diversity $\left(\pi_{d, c p}\right)$ from 0 to 0.00065 in

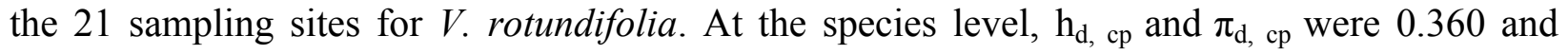
0.00010 , respectively. When excluding six poorly sampled populations, $\mathrm{h}_{\mathrm{d} \text {, cp }}$ and $\pi_{\mathrm{d} \text {, cp }}$ slightly changed to 0.363 and 0.00010 , respectively. Within the four $V$. trifolia sampling sites, $\mathrm{h}_{\mathrm{d}, \mathrm{cp}}$ ranged from 0 to 0.639 and $\pi_{\mathrm{d} \text {, cp }}$ from 0 to 0.00065 , and at the species level, $\mathrm{h}_{\mathrm{d}, \text { cp }}$ was 0.812 and $\pi_{\mathrm{d} \text {, cp }}$ was 0.00039 . These results indicated that both $V$. rotundifolia and $V$. trifolia have relatively low genetic diversity. The highest haplotype diversity occurred in population $\mathrm{WN}$ for $V$. rotundifolia and 3_YN for $V$. trifolia, indicating that Wanning of Hainan Province and Xishuangbanna of Yunnan Province may be the centers of biological diversity of $V$. rotundifolia and $V$. trifolia, respectively.

The length of the ITS sequence was 334 bp for 177 individuals, but only two haplotypes and one polymorphic site were found in $V$. rotundifolia and $V$. trifolia (Fig. 3, Table 3). In 23 sampling sites for $V$. rotundifolia, the total haplotype diversity $\left(\mathrm{h}_{\mathrm{d}, \mathrm{nr}}\right)$ was 0.440 , the range of haplotype diversities within population was from $0-0.667$; the nucleotide diversity $\left(\pi_{\mathrm{d}}\right.$, nr $)$ was 0.00000; and the range of nucleotide diversities within population was $0-0.00200$. When we excluded six poorly sampled populations, the ITS total $h_{d, n r}$ and $\pi_{d, n}$ slightly changed to 0.443 and 0.00000 , respectively. Within the four $V$. trifolia sampling sites, the total values of $\mathrm{h}_{\mathrm{d}, \mathrm{nr}}$ and 
209

210

211

212

213

214

215

216

217

218

219

220

221

222

223

224

225

226

227

228

229

230

231

232

233

234

235

$\pi_{\mathrm{d}, \mathrm{nr}}$ were 0.516 and 0.00000 , respectively. These results indicated that based on the ITS nuclear sequence, $V$. rotundifolia and $V$. trifolia both have a low genetic diversity.

Furthermore, PermutCpSSR_1.2.1 analysis based on cpDNA sequences deduced that the $h_{\mathrm{T}}$, $V_{\mathrm{T}}, h_{\mathrm{S}}$, and $V_{\mathrm{S}}$ values for $V$. rotundifolia were $0.281,0.285,0.225$, and 0.285 , respectively, and those for the $V$. trifolia populations were $0.869,0.921,0.690$, and 0.553 , respectively, indicating that $V$. rotundifolia populations also have low genetic diversity, and that the genetic diversity of the $V$. trifolia populations was much higher than that of $V$. rotundifolia populations. The parameters of $h_{\mathrm{T}}, V_{\mathrm{T}}, h_{\mathrm{S}}$, and $V_{\mathrm{S}}$ based on ITS sequence could not be calculated because only two haplotypes were found in $V$. rotundifolia and $V$. trifolia.

AMOVA analysis based on the cpDNA sequences revealed that a total of $79.19 \%$ of the variation was between the $V$. rotundifolia and $V$. trifolia populations, and $80.36 \%$ of the total cpDNA variation existed within $V$. rotundifolia populations. In addition, $78.25 \%$ of the variations based on cpDNA were found between $V$. rotundifolia and $V$. trifolia populations $(\mathrm{P}<$ 0.01; Table 3), indicating that there was a significant genetic differentiation between these two species. Based on ITS sequences from combined $V$. rotundifolia and $V$. trifolia populations, AMOVA analysis showed that $6.29 \%$ of the variation existed between the species, $6.70 \%$ of the variation was caused by differences between the populations within the species, and $87.02 \%$ of the variation existed within the populations (Table 4).

\subsection{Population structure and phylogeographical analysis}

The phylogeographical analysis based on the cpDNA sequences found that the $N_{\mathrm{ST}}$ value was significantly greater than the corresponding $G_{\mathrm{ST}}$ value $(0.751$ vs. $0.436, \mathrm{P}<0.05)$, showing a noticeable phylogeographical structure across $25 \mathrm{~V}$. rotundifolia and $\mathrm{V}$. trifolia populations, and the eight haplotypes displayed a clear geographical pattern. However, the $\mathrm{N}_{\mathrm{ST}}$ value was higher than its corresponding $\mathrm{G}_{\mathrm{ST}}$ value $(0.462$ vs. $0.201, \mathrm{P}>0.05)$ in 21 V. rotundifolia populations, indicating that there was an unclear cpDNA phylogeographical structure. As shown in Fig 4, statistical parsimony analysis found a single haplotype network based on cpDNA samples of $V$. rotundifolia and $V$. trifolia populations. Furthermore, the TCS 1.21 network analysis of cpDNA 
236 haplotypes revealed the relationship of the interior (ancestral) and the tip (derived) haplotypes.

237 Haplotype H4 was inferred as the ancestral haplotype, as determined by outgroup weight based

238 on haplotype positions in the network. H1, H7, and, H8 were shared only by V. rotundifolia. H2-

239 H6 were shared only by $V$. trifolia. H1 was the most frequent and widely distributed haplotype in

24017 of the 21 populations of $V$. rotundifolia.

241 The phylogenetic relationships between the eight cpDNA haplotypes were assessed under

242 Bayesian inferences drawn using $V$. negundo as an outgroup. The result showed that the 243 phylogenetic tree of the eight cpDNA haplotypes had a comb-like structure (Fig. 5). This result 244 may have been caused by insufficient information sites, or by the rapid expansion of $V$. 245 rotundifolia and $V$. trifolia. We could not perform the haplotype network and phylogenetic 246 analyses based on the ITS sequences because there were only two haplotypes.

\section{$247 \quad 2.3$ Divergence times and demographic history}

248 BEAST, a program for Bayesian analysis, was used to estimate the divergence times. The result 249 showed that the effective sample size (ESS) value ranged from 919 to 1070 for all the nodes, the 250 divergence time between $V$. rotundifolia and $V$. trifolia was 0.23 mya $(0.096-0.396,95 \%$ highest 251 posterior density (HPD)) (Fig. 6). Hence, the divergence between $V$. rotundifolia and $V$. trifolia 252 appeared during the late Pleistocene era.

Based on the cpDNA data, mismatch distribution analysis was performed to test whether the current expansion occurred in $V$. rotundifolia populations and $V$. trifolia populations separately. The results found that $V$. rotundifolia and $V$. trifolia populations each had a relatively smooth unimodal distribution, which was consistent with distribution under an exponential growth rate (Fig. 7), indicating that the two species had a rapid demographic expansion. In addition, among the $21 \mathrm{~V}$. rotundifolia populations, Tajima's $D$ and Fu's test gave apparently positive results, as evidenced by the value of $D$ and $F \mathrm{~s}(\mathrm{D}=-0.3997, F \mathrm{~s}=0.2787$; both $P>0.05)$, indicating that $V$. rotundifolia has not passed through a recent demographic expansion. In the four $V$. trifolia population, Tajima's $D(D=1.8690, P>0.05)$ and Fu's $F \mathrm{~s}(F \mathrm{~s}=0.95759, P>0.05)$ tests also showed no demographic expansion (Table 5). This result is inconsistent with that derived from 
263 the mismatch distribution plots. This discrepancy might be caused the insufficient number of

264

265

266

267

268

269

270

271

272

273

274

275

276

277

278

279

280

281

282

283

284

285

286

287

288

289 variable sites provided by only two pairs of cpDNA regions ( $\operatorname{trn} G$-trnS and $p s b A-\operatorname{trn} H$ ).

\section{Discussion}

\subsection{A large-scale distribution and low genetic diversity of $V$. rotundifolia}

V. rotundifolia is native to seashores from eastern India to Hawaii and from Japan to Australia, and can also be found in Brazil, Mauritius, Bangladesh, and Sri Lanka (Moldenke, 1977; Munir, 1987). In China, V. rotundifolia grows on the beach, seaside, and lakeside, mainly along the eastern coastal region (Wang et al. 2013). Based on our fieldwork, we investigated 14 sampling sites throughout the coastal areas and three sampling sites at lakesides in inland of China. The whole distribution areas of $V$. rotundifolia in China were covered and also extended to Korea and Japan, including sites with few samples. The latitude and longitude of these locations range from $18^{\circ} 44^{\prime} 4.68$ to $39^{\circ} 51^{\prime} 26.24^{\prime \prime}$ and from $9^{\circ} 28^{\prime} 37.83^{\prime \prime}$ to $140^{\circ} 0^{\prime} 46.99^{\prime \prime}$, with the sampling distance crossing almost $3000 \mathrm{~km}$. However, the present study found that $V$. rotundifolia has extremely low levels of genetic diversity $\left(h_{d, c p}=0.360, \pi_{d, c p}=0.00010 ; h_{d, n r}=0.440, \pi_{d, n r}=0.00000\right)$ compared with most other plants (Yan, 2007; Chen et al., 2008; Chen et al., 2012; Xing et al., 2017). Such low level of nucleotide diversity has also been found in the coastal plant Rhizophora (Rhizophoraceae), with nucleotide diversities for trnG-trnS and trnH-rpl2 being $0.04 \pm 0.02$ and $0.03 \pm 0.02$, respectively, and $\pi_{n r}=0.02 \pm 0.01$ (Lo, Duke \& Sun, 2014). However, for $V$. rotundifolia, using allozyme markers (Yeeh et al. 1996) and ISSR markers (Hu et al. 2008), moderate genetic diversity was reported, which was slightly higher than that observed in the present study. This discrepancy might be attributed to differences molecular markers used. In the present study, even when excluding poorly sampled populations, the secondary analysis also indicated that both the chloroplast and nuclear sequences have extremely low nucleotide diversity in $V$. rotundifolia.

The large-scale distribution of $V$. rotundifolia with a low level of genetic diversity may be attributed to three reasons: (1) Long-distance dispersal (LDD) by sea-drifted fruit: Long-distance 
290

291

292

293

294

295

296

297

298

299

300

301

302

303

304

305

306

307

308

309

310

311

312

313

314

315

316

dispersal can result in the homogeneous distribution of DNA haplotypes at the spatial scale (Miryeganeh, 2013). Our results revealed that 17 of the $21 \mathrm{~V}$. rotundifolia sampling sites, including the most distant populations covered by the geographical distribution range of sampling, such as XL (Xinglong of Hainan province) and JP (Japan), shared the common haplotype H1. This wide distribution of haplotypes may be caused by long-distance dispersal of this plant's fruit. The $V$. rotundifolia fruit is covered with a thick hydrophobic coating that can resist water penetration, rendering it able to float in the ocean, drift onto the beach, and disperse over long distance via sea drift (Munir, 1987; Cousins et al., 2010). Therefore, this rapid longdistance dispersal ability of $V$. rotundifolia fruit may be responsible for the low genetic diversity of this plant. (2) The similar ecological environment: Life history traits and environmental factors affect the genetic diversity and structure of species (Loveless \& Hamrick, 1984; Nybom, 2004). V. rotundifolia usually grows on beaches, sand dunes, and rocky shorelines at low elevations and can tolerate the highly salt, drought, full sun, and sandy or well-drained soils (http://www2.hawaii.edu/ eherring/hawnprop/vit-rotu.htm). These similar ecological niches could limit genetic differences and lead to a low genetic diversity of $V$. rotundifolia. (3) The asexual reproductive mode: This species proliferates by sexual reproduction, as well as clonal propagation through the elongation of rhizomes and root systems (http:/hgic.clemson.edu/factsheets /HGIC2315.htm; Gresham \& Neal, 2004). Clonal reproduction usually leads to the loss of genetic diversity within populations (Cook, 1983).

\subsection{Population structure and demographic history}

Based on the cpDNA data, the results showed that all populations of $V$. rotundifolia and $V$. trifolia had a significant phylogeographical structure $\left(\mathrm{G}_{\mathrm{ST}}=0.436, \mathrm{~N}_{\mathrm{ST}}=0.751 ; \mathrm{N}_{\mathrm{ST}}>\mathrm{G}_{\mathrm{ST}}, P<\right.$ 0.05). The current distribution of haplotypes may be caused by climate oscillation during the Quaternary period, which resulted in further large-scale migration of most plants and animals, and the subsequent accumulation of genetic variations and specific phylogeographical structures (Hewitt, 2000, 2004). V. rotundifolia populations showed an insignificant phylogeographical structure. $\left(\mathrm{G}_{\mathrm{ST}}=0.201, \mathrm{~N}_{\mathrm{ST}}=0.462 ; \mathrm{N}_{\mathrm{ST}}>\mathrm{G}_{\mathrm{ST}}, P>0.05\right)$. Furthermore, AMOVA analysis 
317 showed low genetic differentiation among $V$. rotundifolia populations, indicating that rapid 318 spread by sea currents may have played a key role. The unclearly phylogeographical structure 319 and the low genetic differentiation in $V$. rotundifolia populations may relate to the rapid long320 distance dispersal by sea drifts. This is not consistent with the report by $\mathrm{Hu}$ et al (2008), in which

ISSR analysis showed a relatively high genetic differentiation $(\mathrm{Gst}=0.587)$ among populations of $V$. rotundifolia; the authors stated that such characteristics of $V$. rotundifolia are likely attributed to its sexual/asexual reproduction and limited gene flow. These contradictory results may have been caused by the different gene markers used (ISSR vs. cpDNA).

Estimated divergence times indicated that the genetic divergence between $V$. rotundifolia and V. trifolia occurred about 0.23 mya (0.096-0.396, 95\% HPD), indicating a relatively short divergence time, corresponding to the late Pleistocene era, before the onset of the last glacial maximum (LGM). Following this divergence, long-distance dispersal may have been a major historical process for $V$. rotundifolia, because they are present throughout the Pacific, including the coastal areas of the continents and many islands. Additionally, we detected a recent population expansion of $V$. rotundifolia based on the apparent mismatch distribution, showing that $V$. rotundifolia had undergone a long-distance dispersal expansion in the short term.

The ancestral haplotypes are located in a central position within the phylogeographical network (Crandall \& Templeton, 1993). Haplotype H4 is located in the center of the haplotype network, and is the closest haplotype to H9 (outgroup), and H1 has evolved from H4. Therefore, we suggest that $\mathrm{H} 4$ is the ancestral haplotype, which was detected in two populations (3_WC and 3_YN) in V. trifolia. Populations 3_WC and 3_YN are from the southern part of China and have higher haplotype diversities in all populations. Moreover, the results of the TCS network analysis also showed that the haplotypes shared by $V$. rotundifolia were deduced from those of $V$. trifolia. Thus, we speculated that Yunnan and Wenchang regions might be two origin areas of $V$. rotundifolia. During the Quaternary period, V. rotundifolia expanded to eastern China rapidly.

The analysis of cpDNA data in this study showed that the $V$. rotundifolia and $V$. trifolia populations have no shared haplotypes. In addition, analysis of molecular variance (AMOVA) 
344 showed a significant difference in genetic differentiation between $V$. rotundifolia and $V$. trifolia $345\left(F_{S T, c p}=0.79195\right)$. These findings supported the view that $V$. rotundifolia and $V$. trifolia are two 346 separate species.

\section{$347 \quad 3.3$ Conservation strategy}

348 It is essential to study the morphological variation, genetic diversity, and population structure to 349 provide basic information on plant conservation (Feng, Wang \& Gong, 2014; Fan et al., 2017). 350 Climate change, the rapid growth of the human population, and economic development all

351

352

353 contribute to the deterioration of $V$. rotundifolia's habitat, reducing the number of individuals in some populations. Therefore, $V$. rotundifolia resource protection is urgently required. The management priority is to conserve the population of the species that has the greatest diversity. Our results showed that the WN, XL, and QD populations have the highest haplotype diversity and nucleotide diversity in $V$. rotundifolia; therefore, conservation priority should be considered for these populations. $\mathrm{Hu}$ et al. (2008) proposed that the Xinjian population of $V$. rotundifolia from Jiangxi province of China had a considerably high genotypic diversity index and should be prioritized for protection measures.

Furthermore, population size is an important factor threatening the existence of species, and for many wildlife species, conservation should prioritize the smallest populations. Our field surveys found that most extant $V$. rotundifolia populations in China face a serious threat of extinction because of the limited number of individuals. Therefore, initial conservation measures for $V$. rotundifolia should be considered to increase the population size and genetic diversity. Among the extant populations, there are fewer than 10 individuals in the DL, LYG, and XL populations. Hence, we need to increase the population size for in situ conservation with high priority in these populations. In addition, habitat protection is also an important concern in $V$. rotundifolia conservation because of habitat damage by increased human activities and over-exploitation of the plant as a medical resource. Therefore, it is necessary to establish local nature reserves, especially for those small-sized and seriously disturbed populations. Ex situ conservation strategies, including germplasm collection, culture in botanical gardens (Kunming, Beijing), or 
371

372

373

374

375

376

377

378

379

380

381

382

383

384

reintroductions at appropriate areas with similar habitats, are also effective measures to preserve the genetic resources of $V$. rotundifolia. When the ex situ conservation is put in practice, samples should be collected from as many individuals as possible, because a large portion of the genetic diversity exists within, rather than among, populations. Sample collection from the WN, XL, and QD populations is recommended. Our experience, together with the results from previous studies, suggested that individuals in a population should be collected at $>20 \mathrm{~m}$ spatial intervals to avoid collecting individuals with identical or similar genotypes (Hu et al., 2008).

\section{Conclusions}

In summary, the present studies revealed the intraspecific genetic variation pattern of $V$. rotundifolia and $V$. trifolia, and identified genetic divergence that occurred during the late Pleistocene era. Our results showed that $V$. rotundifolia underwent a rapid long-distance dispersal expansion with low genetic differentiation among populations with an unclear phylogeographical structure. In addition, it has a low level of genetic diversity with a large-scale distribution. In conservation terms, the populations containing high genetic diversity (WN, XL, and QD) should be protected. A balanced and dynamic conservation strategy for $V$. rotundifolia has been proposed.

Acknowledgments: We thank Yang Yang for providing samples for this study and for his initial help with lab work, Shunxing Zhang, Baorong Lu and Yanghaoyu (Jason) Chen for the Englishlanguage revisions.

\section{References}

Avise., John C. 2000. Phylogeography: the history and formation of species. Harvard University Press.

Barger TW., Horne HE., Spaulding DD., Holt BD., Cressler A., Estes LD., Hughes BM. 2012. 
New and Noteworthy Records for the Flora of Alabama. Castanea 77:257-269.

Cantino PD. 1992. Toward a phylogenetic classification of the Labiatae. Advances in Labiate Science, 27-37.

Chang, C.S., Kim, H. \& Chang KS. 2014. Provisional Checklist of Vascular Plants for the Korea Peninsula Flora (KPF). Designpost, Korea.

Chen K., Abbott RJ., Milne RI., Tian XM., Liu J. 2008. Phylogeography of Pinus tabulaeformis Carr. (Pinaceae), a dominant species of coniferous forest in northern China. Molecular Ecology 17:4276. DOI: 10.1111/j.1365-294X.2008.03911.x.

Chen SC., Zhang L., Zeng J., Shi F., Yang H., Mao YR., Cheng-Xin FU. 2012. Geographic variation of chloroplast DNA in Platycarya strobilacea(Juglandaceae). Journal of Systematics and Evolution 50:374-385. DOI: 10.1111/j.1759-6831.2012.00210.x.

Clegg MT., Gaut BS., Jr LG., Morton BR. 1994. Rates and patterns of chloroplast DNA evolution. Proceedings of the National Academy of Sciences of the United States of America 91:6795-6801. DOI: 10.1073/pnas.91.15.6795.

Clement M., Posada D., Crandall KA. 2000. TCS: a computer program to estimate gene genealogies. Molecular Ecology 9:1657-1659._DOI: 10.1046/j.1365-294x.2000.01020.x.

Cook R. 1983. Clonal plant populations. American Scientist 71:244-253.

Cousins MM., Briggs J., Gresham C., Whetstone J., Whitwell T. 2010. Beach Vitex (Vitex rotundifolia): An Invasive Coastal Species. Invasive Plant Science and Management 3:340345. DOI: 10.1614/IPSM-D-09-00055.1.

Crandall KA., Templeton AR. 1993. Empirical tests of some predictions from coalescent theory with applications to intraspecific phylogeny reconstruction. Genetics 134:959-969.

Drummond AJ, Ashton B, Buxton S, Cheung M, Cooper A, Duran C, Field M, Heled J, Kearse M, Markowitz S, Moir R, Stones-Havas S, Sturrock S, Thierer T WA.Geneious v4.8.5 Available at http://www.geneious.com/ (accessed Nov 15, 2017).

Drummond AJ., Suchard MA., Xie D., Rambaut A. 2012. Bayesian Phylogenetics with BEAUti and the BEAST 1.7. Molecular Biology \& Evolution 29:1969-1973. DOI: 
425

426

427

428

429

430

431

432

433

434

435

436

437

438

439

440

441

442

443

444

445

446

447

448

449

450

451

10.1093/molbev/mss075.

Editorial Committee of Chinese Pharmacopoeia. 2015. Pharmacopoeia of the People's Republic of China. 363.

Eyrewalker A. 2000. Fundamentals of Molecular Evolution (2nd edn). Heredity 84:735.

Excoffier L., Lischer HE. 2010. Arlequin suite ver 3.5: a new series of programs to perform population genetics analyses under Linux and Windows. Molecular Ecology Resources 10:564. DOI: 10.1111/j.1755-0998.2010.02847.x.

Fan Y., Zhang C., Wu W., He W., Zhang L., Ma X. 2017. Analysis of Genetic Diversity and Structure Pattern of Indigofera Pseudotinctoria in Karst Habitats of the Wushan Mountains Using AFLP Markers. Molecules 22:1734. DOI: 10.3390/molecules22101734.

Feng X., Wang Y., Gong X. 2014. Genetic diversity, genetic structure and demographic history of Cycas simplicipinna (Cycadaceae) assessed by DNA sequences and SSR markers. Bmc Plant Biology 14:187. DOI: 10.1186/1471-2229-14-187.

Franck AR., Anderson LC., Burkhalter JR., Dickman S. 2016. Additions to the flora of Florida, U.S.A. (2010-2015). Journal of the Botanical Research Institute of Texas 10:175-190.

GeoResources Institute(GRI). Available at http://hgic.clemson. edu/factsheets/HGIC2315.htm (accessed June 15, 2018).

Gresham CA., Neal A. 2004.An Evaluation of the Invasive Potential of Beach Vitex (Vitex rotundifolia). Available at http://hgic.clemson.edu/factsheets/HGIC2315.htm (accessed June $15,2018)$.

Hamilton MB. 1999. Four primer pairs for the amplification of chloroplast intergenic regions with intraspecific variation. Molecular Ecology 8:521-523.

Harley, R. M., S. Atkins, A. L. Budantsev, P. D. Cantino, B. J. Conn, R. Grayer, M. M. Harley, et al. 2004. Labiateae. In J. W. Kadereit [ed.], VII. Flowering plants: Dicotyledons. Lamiales (except Acanthaceae including Avicenniaceae), 167-275. Springer, Berlin, Germany.

Hawaiian Native Plant Propagation Database 2018. Available at 
452

453

454

455

456

457

458

459

460

461

462

463

464

465

466

467

468

469

470

471

472

473

474

475

476

477

478

http://www2.hawaii.edu/ eherring/hawnprop/vit-rotu.htm (accessed June 15, 2018).

Hewitt G. 2000. The genetic legacy of the Quaternary ice ages. Nature 405:907-913. DOI:10.1038/35016000.

Hewitt GM. 2004. Genetic consequences of climatic oscillations in the Quaternary. Philos Trans R Soc Lond B Biol Sci 359:183-195. DOI:10.1098/rstb.2003.1388.

Hu Y., Zhang Q., Xin H., Qin LP., Lu BR., Rahman K., Zheng HC. 2007. Association between chemical and genetic variation of Vitex rotundifolia populations from different locations in China: its implication for quality control of medicinal plants. Biomedical Chromatography 21(9):967-75. DOI:10.1002/bmc.841.

Hu Y., Zhu Y., Zhang QY., Xin HL., Qin LP., Lu BR., Rahman K., Zheng HC. 2008. Population genetic structure of the medicinal plant Vitex rotundifolia in China: implications for its use and conservation. Journal of integrative plant biology 50:1118-1129. DOI: 10.1111/j.17447909.2008.00635.x.

Kim KD. 2005. Invasive plants on disturbed Korean sand dunes. Estuarine Coastal \& Shelf Science 62:353-364. DOI: org/10.1016/j.ecss.2004.09.023.

Kok RPJ De. 2007. The genus Vitex L (Lamiaceae) in New Guinea and the South Pacific Islands. Kew Bulletin 62:587-603.DOI: org/10.1016/j.

Kok R De. 2008. The genus Vitex ( Labiatae ) in the Flora Malesiana region, excluding New Guinea. Kew Bulletin 63:17-40. DOI: org/10.1007/s12225-007-9013-7.

Kumar R., Kumar V. 2018. A review of phylogeography: biotic and abiotic factors. Geology, Ecology, and Landscapes (2018):1-7.

Librado P., Rozas J. 2009. DnaSP v5: a software for comprehensive analysis of DNA polymorphism data. Bioinformatics 25:1451-1452. DOI: 10.1093/bioinformatics/btp187.

List of national key protected wild herbs species. Available at http://www.cites.org.cn/article/show.php?itemid=589 (accessed June 15, 2018).

Lo EY., Duke NC., Sun M. 2014. Phylogeographic pattern of Rhizophora (Rhizophoraceae) reveals the importance of both vicariance and long-distance oceanic dispersal to modern 
mangrove distribution. Bmc Evolutionary Biology 14:83. DOI: 10.1186/1471-2148-14-83.

Loveless MD., Hamrick JL. 1984. Ecological Determinants of Genetic Structure in Plant

Populations. Annual Review of Ecology \& Systematics 15:65-95.

Millar CI, Libby WJ. 1991. Strategies for conserving clinal, ecotypic, and disjunct population diversity in widespread species. New York: Oxford University Press.

Miryeganeh M. 2013. Phylogeography of a Pantropical Plant with Sea-drifted Seeds, Ipomoea pes-caprae (L.) Roth., (Convolvulaceae). Chiba University.

Moldenke HN. 1977. A sixth summary of the Verbenaceae, Avicenniaceae, Stilbaceae, Chloanthaceae, Symphoremaceae, Nyctanthaceae, and Eriocaulaceae of the world as to valid taxa, geographic distribution and synonymy. Supplement 2. Canadian-American Slavic Studies 3:754-755(2).

Munir AA. 1987. A taxonomic revision of the geneus Vitex L.(Verbenaceae) in Australia. Journal of the Adelaide Botanic Garden 10:31-79.

Nybom H. 2004. Comparison of different nuclear DNA markers for estimating intraspecific genetic diversity in plants. Molecular Ecology 13:1143-1155. DOI: org 10.1111/j.1365294X.2004.02141.x.

Ohtsuki T., Shoda T., Kaneko Y., Setoguchi H. 2014. Development of Microsatellite Markers for Vitex rotundifolia ( Verbenaceae), an Endangered Coastal Plant in Lake Biwa, Japan. Applications in Plant Sciences 2:4-7. DOI: 10.3732/apps.1300100.

Petit RJ., Pineau E., Demesure B., Bacilieri R., Ducousso A., Kremer A. 1997. Chloroplast DNA footprints of postglacial recolonization by oaks. Proceedings of the National Academy of Sciences of the United States of America 94:9996.

Pons O., Petit RJ. 1996. Measwring and Testing Genetic Differentiation With Ordered Versus Unordered Alleles. Genetics 144:1237-1245.

Posada D., Crandall KA. 1998. MODELTEST: testing the model of DNA substitution. Bioinformatics 14:817-818._DOI: 10.1093/bioinformatics/14.9.817.

Ronquist F., Teslenko M., Mark P Van Der., Ayres DL., Darling A., Höhna S., Larget B., Liu L., 
506

507

508

509

510

511

512

513

514

515

516

517

518

519

520

521

522

523

524

525

526

527

528

529

530

531

532

Suchard MA., Huelsenbeck JP. 2012. MrBayes 3.2: Efficient Bayesian Phylogenetic Inference and Model Choice Across a Large Model Space. Systematic Biology 61:539_ 542. DOI: 10.1093/sysbio/sys029.

Shaw J., Lickey EB., Schilling EE., Small RL. 2007. Comparison of whole chloroplast genome sequences to choose noncoding regions for phylogenetic studies in angiosperms: the tortoise and the hare III. American Journal of Botany 94:275. DOI: 10.3732/ajb.94.3.275.

Sung CK., Kimura T., But PPH., Guo JX. 1996. International Collation of Traditional and Folk Medicine:Northeast Asia - Part I. Singapore: WORLD SCIENTIFIC.

Tanaka N., Jinadasa KBSN., Mowjood MIM., Fasly MSM. 2011. Coastal vegetation planting projects for tsunami disaster mitigation: effectiveness evaluation of new establishments. Landscape \& Ecological Engineering 7:127-135.

The International Plant Names Index (2012). Available athttp://www.ipni.org/ (accessed June 15, 2018).

Wang ZR, He ZR KM. 2013. Wu Z-Y, Raven PH HD-Y ed. Flora of China. Beijing,St. Louis: Science Press, Missouri Botanical Garden Press, 28-32.

Weitemier K., Straub SC., Fishbein M., Liston A. 2015. Intragenomic polymorphisms among high-copy loci: a genus-wide study of nuclear ribosomal DNA in Asclepias (Apocynaceae). Peerj 3:e718. DOI: 10.7717/peerj.718.

Wolfe KH., Li WH., Sharp PM. 1987. Rates of nucleotide substitution vary greatly among plant mitochondrial, chloroplast, and nuclear DNAs. Proceedings of the National Academy of Sciences of the United States of America 84:9054._DOI: 10.1073/pnas.84.24.9054.

Xing R., Gao QB., Zhang FQ., Fu PC., Wang JL., Yan HY., Chen SL. 2017. Genetic variation and phylogenetic relationships of the ectomycorrhizal Floccularia luteovirens on the Qinghai-Tibet Plateau. Journal of Microbiology 55:600. DOI: 10.1007/s12275-017-7101-4.

Yan HF. 2007. Phylogeographic structure of Primula obconica (Primulaceae) inferred from chloroplast microsatellites (cpSSRs) markers. Acta Phytotaxonomica Sinica 45:488-496. DOI:10.1360/aps06214. 
533 Yeeh Y., Kang SS., Chung HG., Chung MS., Chung MG. 1996. Genetic and clonal diversity in $534 \quad$ Korean populations of Vitex rotundifolia (Verbenaceae). Journal of Plant Research 535 109:161-168. DOI: 10.1007/BF02344541.

536 Zhang XC, Xu D, Sun W, Song Ming Liu X. 2014. Identification of Viticis Fructus and Its 537 Adulterants by ITS2 Sequence. World Science and Technology/Modernization of 538 Traditional Chinese Medicine and Materia Medica 16:2366-2370. DOI: $539 \quad 10.11842 /$ wst.2014.11.014. 
Figure 1

The sample locations of $V$. rotundifolia and $V$. trifolia were used in this study.

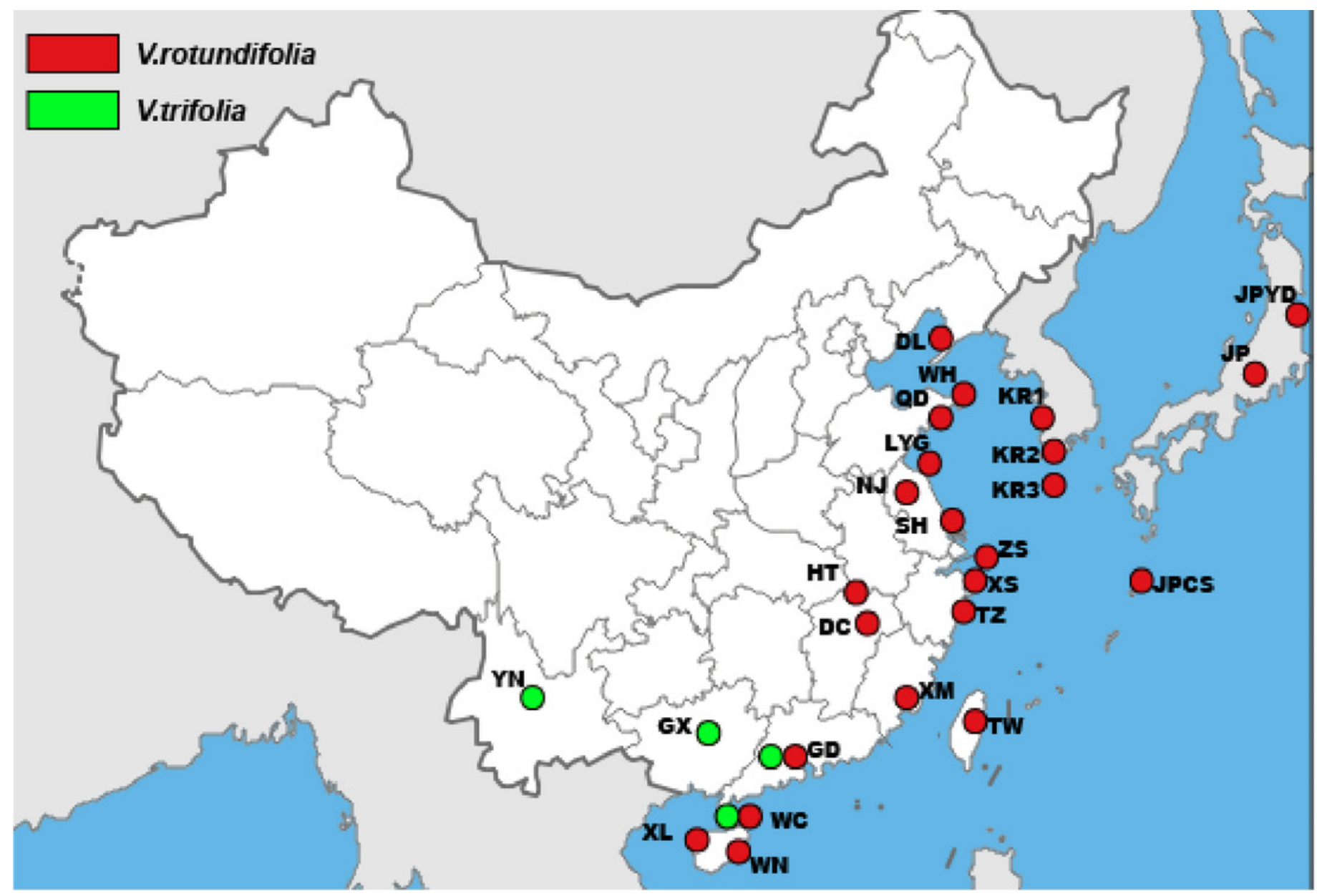


Figure 2

Geographic distribution of the cpDNA haplotypes in V. rotundifolia and V. trifolia.

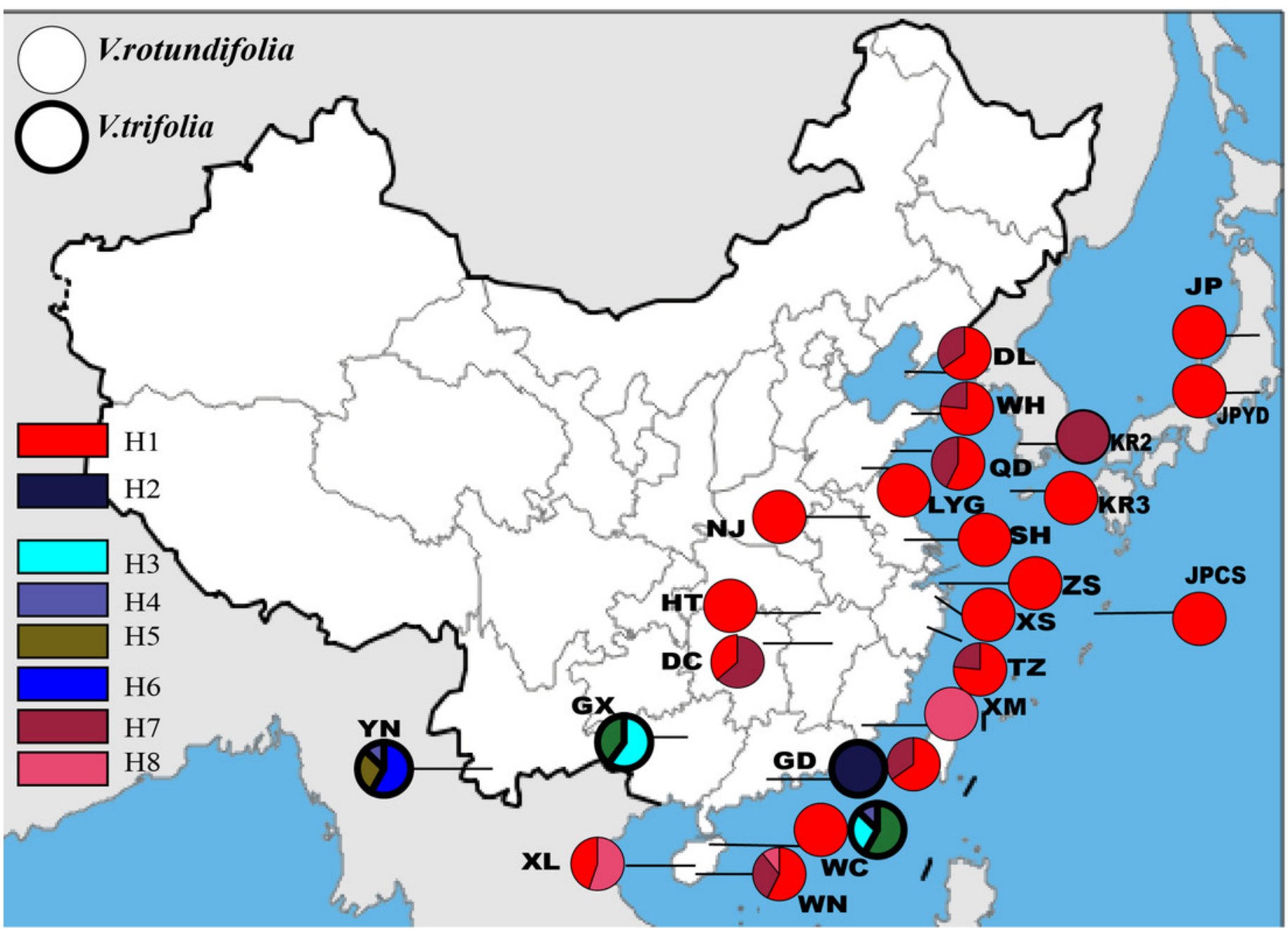


Figure 3

Geographic distribution of the nrDNA haplotypes in V. rotundifolia and V. trifolia.

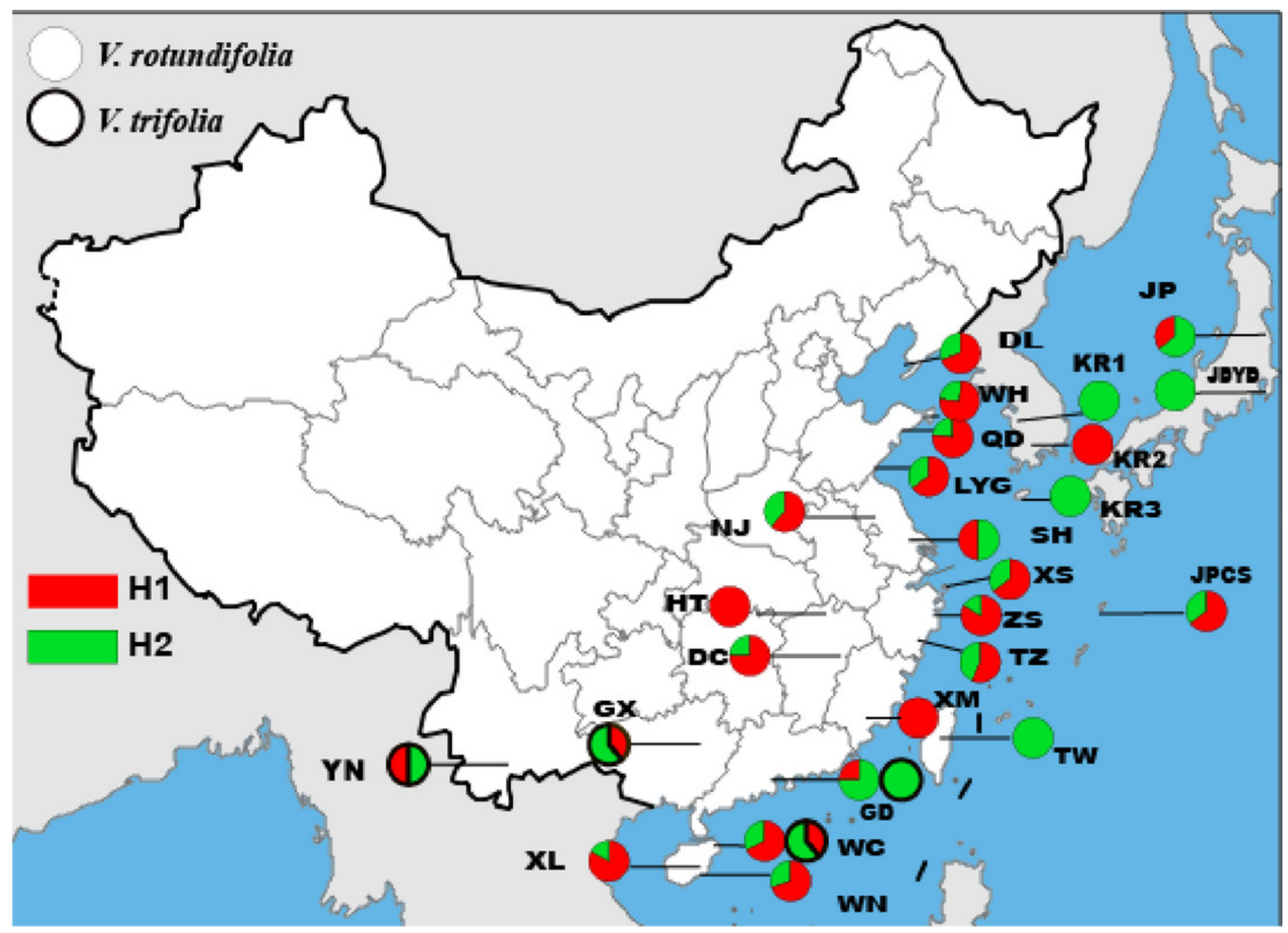




\section{Figure 4}

Minimum spanning network of eight cpDNA haplotypes in $V$. rotundifolia and $V$. trifolia.

The network was rooted at the $V$. negundo. Circle sizes are proportional to the number of samples per haplotypes. Hollow dots indicate the number of mutational steps. 


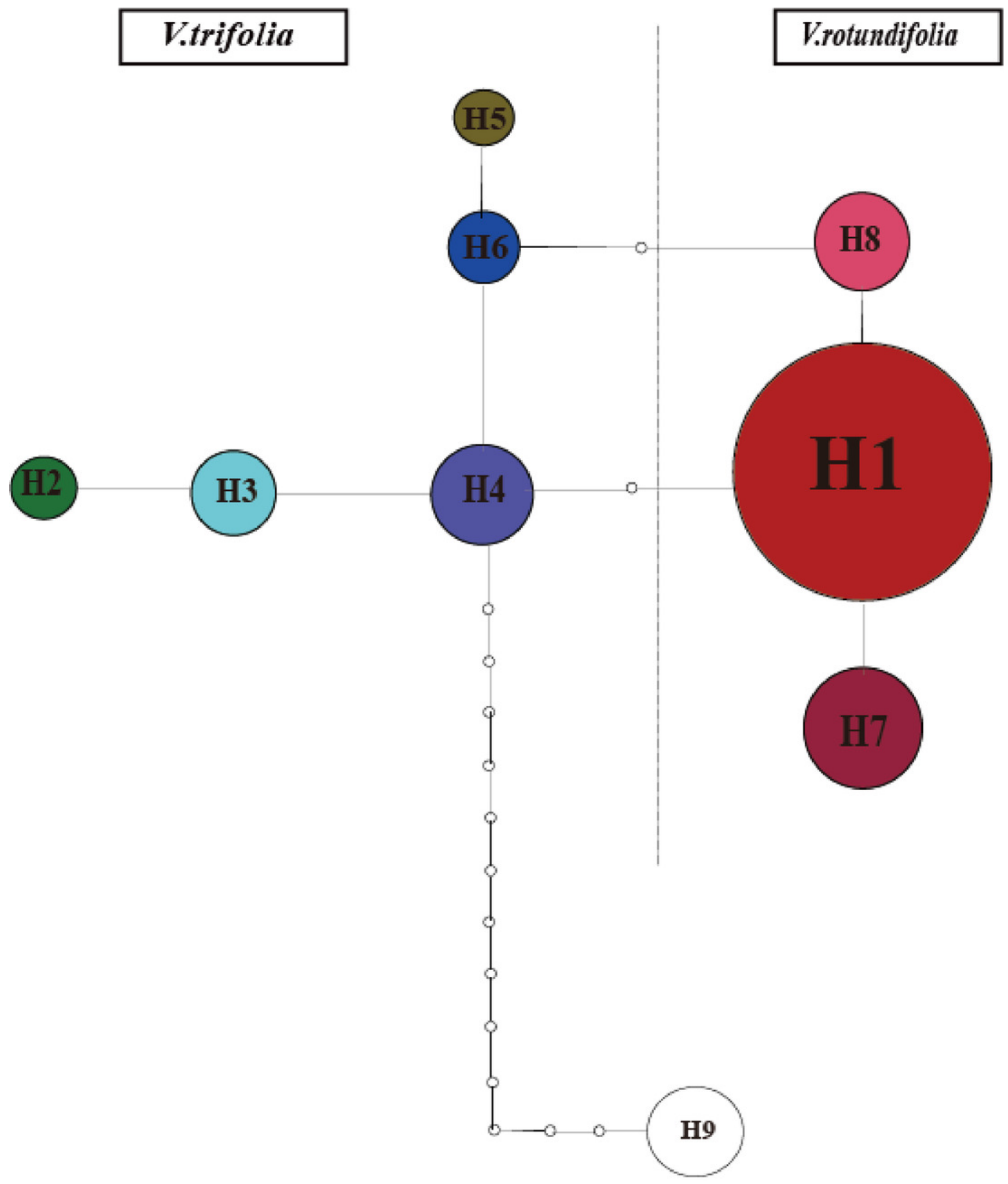


Figure 5

Bayesian inference (BI) phylograms of 9 haplotypes based on chloroplast DNA (cPDNA) sequences.

The $V$. negundo (haplotype 9) was used as outgroup. Posterior probabilities (PP>0.50) are labelled above the nodes.

*Note: Auto Gamma Correction was used for the image. This only affects the reviewing manuscript. See original source image if needed for review.

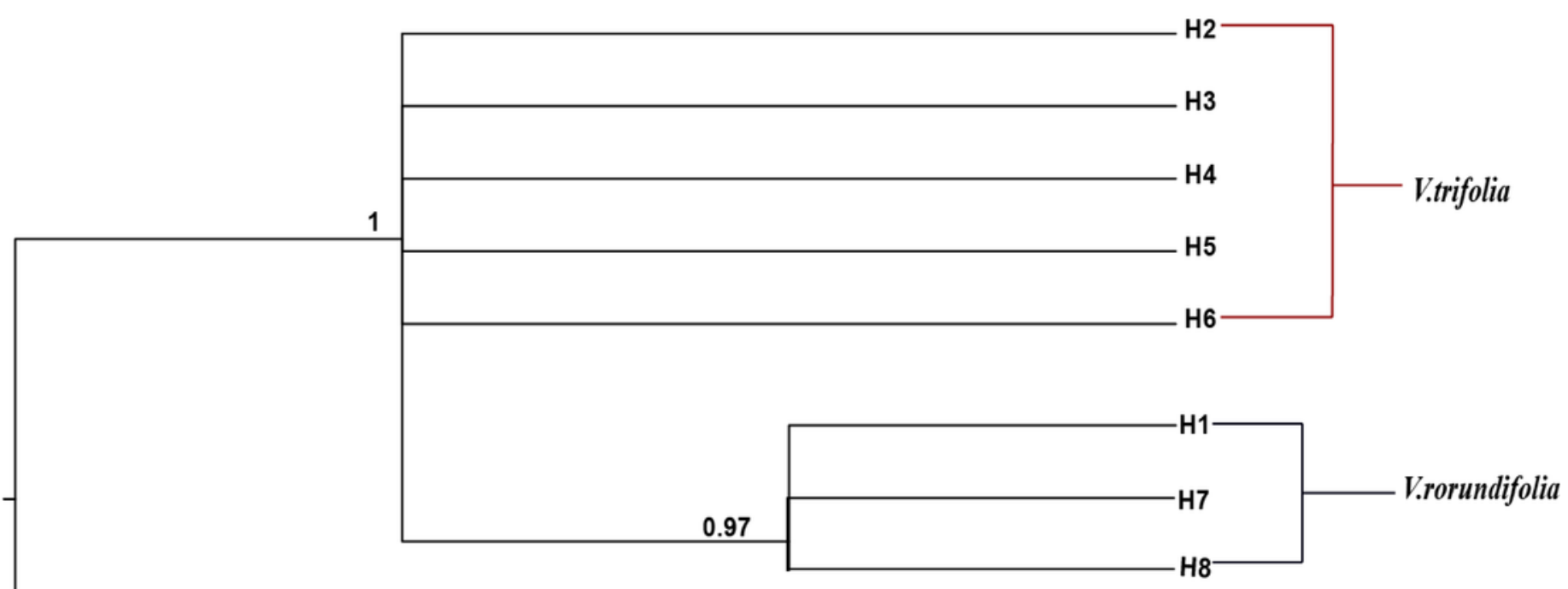


Figure 6

BEAST-derived chronograms of $V$. rotundifolia and $V$. trifolia. based on cpDNA sequences with $V$. negundo used as outgroup.

Posterior probabilities (PP>0.50) are labelled below the nodes. The bars on each node indicate 95\% highest posterior densities (HPDs) of time estimates (years ago).

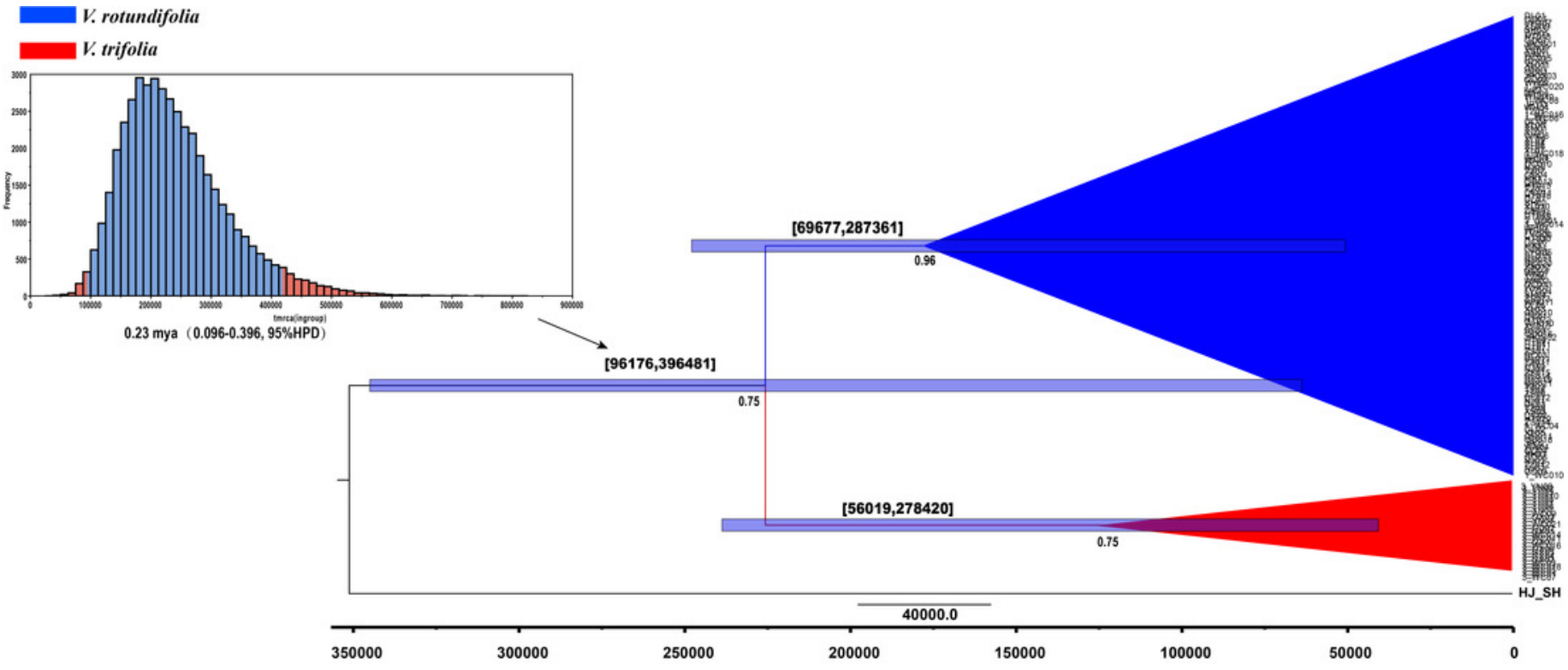




\section{Figure 7}

Mismatch distribution plots for $V$. rotundifolia and $V$. trifolia haplotypes.

Observed (Obs) frequency of pairwise differences versus expected (Exp) under exponential population growth model for major cpDNA sequences, (A) V. rotundifolia. (B) V. trifolia.
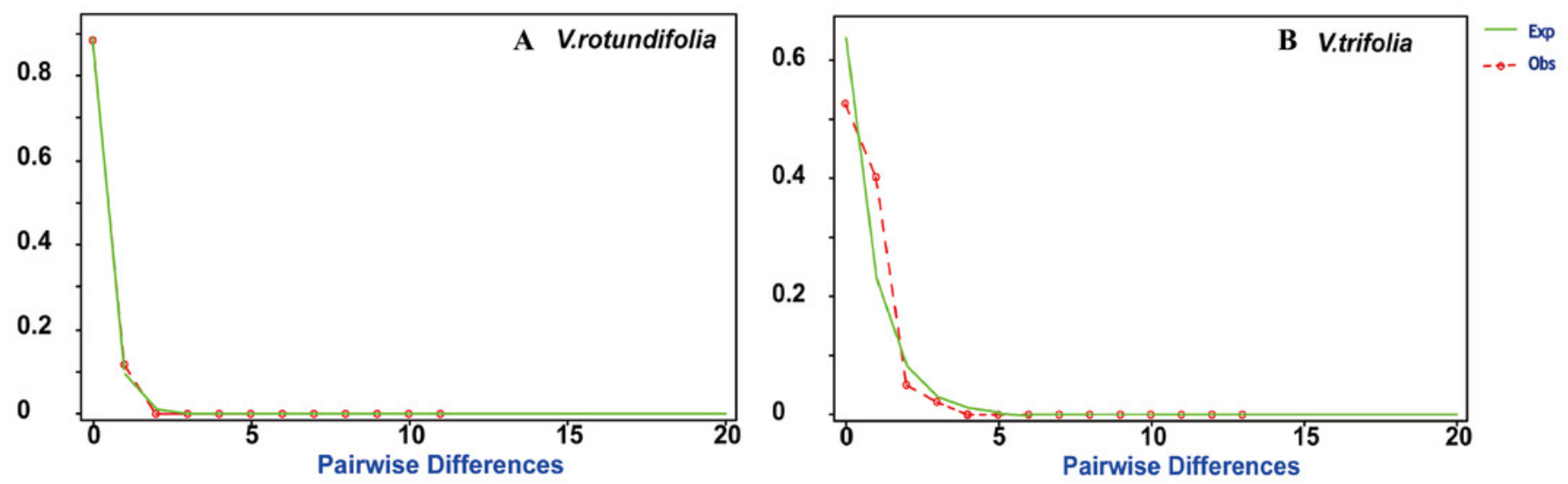


\section{Table $\mathbf{1}$ (on next page)}

Localities and numbers of samples surveyed across the natural range of $V$. rotundifolia and $V$. trifolia and the numbers of haplotypes of cpDNA and nrDNA observed in the populations surveyed.

$n_{s}$, the number of samples analysed; $n_{h}$, the number of haplotypes obsevered; $h$, haplotype diversity; $\pi$, nucleotide diversity. 
Localities and numbers of samples surveyed across the natural range of $V$. rotundifolia and $V$. trifolia and the numbers of

\begin{tabular}{|c|c|c|c|c|c|c|c|c|}
\hline \multicolumn{2}{|c|}{ Population } & $\begin{array}{l}\text { Latitude } \\
(\mathrm{N})\end{array}$ & $\begin{array}{c}\text { Longitude } \\
\text { (E) }\end{array}$ & $\begin{array}{c}\text { Altitude } \\
\text { (m) }\end{array}$ & $\begin{array}{l}\mathbf{n}_{\mathbf{s}, \mathbf{c p} /} \\
\mathbf{n}_{\mathbf{s}, \mathbf{n r}}\end{array}$ & $\begin{array}{l}\mathbf{n}_{\mathbf{h}, \mathbf{c p} /} \\
\mathbf{n}_{\mathbf{h}, \mathbf{n r}}\end{array}$ & $\begin{array}{l}\mathbf{h}_{\mathrm{cp} /} \\
\mathbf{h}_{\mathrm{nr}}\end{array}$ & $\begin{array}{l}\pi_{\mathrm{cp} /} \\
\pi_{\mathrm{nr}}\end{array}$ \\
\hline \multicolumn{9}{|c|}{ Vitex. rotundifolia } \\
\hline DL & Dalian, Liaoning, China & $\begin{array}{l}39^{\circ} 10^{\prime} 11.62 \\
"\end{array}$ & $22^{\circ} 04^{\prime} 40.26^{\prime \prime}$ & 28 & $10 / 11$ & $2 / 2$ & $0.467 / 0.356$ & $\begin{array}{l}0.00042 / \\
0.00106\end{array}$ \\
\hline WH & Weihai, Shandong, China & $\begin{array}{l}37^{\circ} 31^{\prime} 60.75 \\
"\end{array}$ & $22^{\circ} 02^{\prime} .25 .55^{\prime \prime}$ & 6 & $9 / 8$ & $2 / 2$ & $0.389 / 0.429$ & $\begin{array}{l}0.00035 / \\
0.00128\end{array}$ \\
\hline QD & Qingdao, Shandong, China & $\begin{array}{l}36^{\circ} 24^{\prime} 78.35 \\
" \prime\end{array}$ & $20^{\circ} 55^{\prime} 48.07^{\prime \prime}$ & 5 & $9 / 10$ & $2 / 2$ & $0.500 / 0.467$ & $\begin{array}{l}0.00045 / \\
0.00140\end{array}$ \\
\hline LYG & $\begin{array}{l}\text { Lianyungang, Jiangsu, } \\
\text { China }\end{array}$ & $\begin{array}{l}34^{\circ} 45^{\prime} 74.87 \\
\prime \prime\end{array}$ & $9^{\circ} 28^{\prime} 37.83^{\prime \prime}$ & 1 & $4 / 7$ & $1 / 2$ & $0.000 / 0.571$ & $\begin{array}{l}0.00000 / \\
0.00171\end{array}$ \\
\hline $\mathbf{N J}$ & Nanjing, Jiangsu, China & $\begin{array}{l}32^{\circ} 03^{\prime} 20.78 \\
\prime \prime\end{array}$ & $\begin{array}{l}118^{\circ} 49^{\prime} 19.85 \\
"\end{array}$ & 25 & $5 / 5$ & $1 / 2$ & $0.000 / 0.600$ & $\begin{array}{l}0.00000 / \\
0.00180\end{array}$ \\
\hline DC & Duchang, Jiangxi, China & $\begin{array}{l}29^{\circ} 26^{\prime} 06.09 \\
"\end{array}$ & $\begin{array}{l}116^{\circ} 06^{\prime} 42.05 \\
\prime \prime\end{array}$ & 76 & $11 / 12$ & $2 / 2$ & $0.436 / 0.409$ & $\begin{array}{l}0.00039 / \\
0.00123\end{array}$ \\
\hline HT & Houtian, Jiangxi, China & $\begin{array}{l}28^{\circ} 26^{\prime} 20.26 \\
\prime \prime\end{array}$ & $\begin{array}{l}115^{\circ} 48^{\prime} 00.26 \\
\prime \prime\end{array}$ & 39 & $12 / 12$ & $1 / 1$ & $0.000 / 0.000$ & $\begin{array}{l}0.00000 / \\
0.00000\end{array}$ \\
\hline $\mathbf{Z S}$ & $\begin{array}{l}\text { Zhoushan, Zhejiang, } \\
\text { China }\end{array}$ & $\begin{array}{l}29^{\circ} 52^{\prime} 56.42 \\
\prime \prime\end{array}$ & $22^{\circ} 24^{\prime} .02 .03^{\prime \prime}$ & 0 & $9 / 10$ & $1 / 2$ & $0.000 / 0.200$ & $\begin{array}{l}0.00000 / \\
0.00060\end{array}$ \\
\hline XS & $\begin{array}{l}\text { Xiangshan, Zhejiang, } \\
\text { China }\end{array}$ & $\begin{array}{l}29^{\circ} 25^{\prime} 86.14 \\
"\end{array}$ & $21^{\circ} 57^{\prime} 76.63^{\prime \prime}$ & 3 & $2 / 3$ & $1 / 2$ & $0.000 / 0.667$ & $\begin{array}{l}0.00000 / \\
0.00200\end{array}$ \\
\hline $\mathbf{T Z}$ & Taizhou, Zhejiang, China & $28^{\circ} 41^{\prime} 46.83$ & $21^{\circ} 46^{\prime} 54.73^{\prime \prime}$ & 10 & $9 / 12$ & $2 / 2$ & $0.389 / 0.530$ & $0.00035 /$ \\
\hline
\end{tabular}




\begin{tabular}{|c|c|c|c|c|c|c|c|c|}
\hline & & $"$ & & & & & & 0.00159 \\
\hline SH & Shanghai, China & $\begin{array}{l}31^{\circ} 13^{\prime} 55.03 \\
\prime \prime\end{array}$ & $\begin{array}{l}121^{\circ} 28^{\prime} 10.00 \\
\prime \prime\end{array}$ & 13.31 & $4 / 4$ & $1 / 2$ & $0.000 / 0.667$ & $\begin{array}{l}0.00000 / \\
0.00200\end{array}$ \\
\hline $\mathbf{X M}$ & Xiamen, Fujian, China & $\begin{array}{l}24^{\circ} 28^{\prime} 56.93 \\
" \prime\end{array}$ & $118^{\circ} 05^{\prime} 4.03^{\prime \prime}$ & 2 & $1 / 1$ & $1 / 1$ & $0.000 / 0.000$ & $\begin{array}{l}0.00000 / \\
0.00000\end{array}$ \\
\hline GD & $\begin{array}{l}\text { Gangzhou, Guangdong, } \\
\text { China }\end{array}$ & $\begin{array}{l}23^{\circ} 11^{\prime} 21.66 \\
"\end{array}$ & $\begin{array}{l}113^{\circ} 21^{\prime} 31.41 \\
"\end{array}$ & 22 & $11 / 10$ & $2 / 2$ & $0.467 / 0.467$ & $\begin{array}{l}0.00042 / \\
0.00140\end{array}$ \\
\hline 1_WC & $\begin{array}{l}\text { Wenchang, Hainnan, } \\
\text { China }\end{array}$ & $\begin{array}{l}19^{\circ} 32^{\prime} 42.56 \\
\prime \prime\end{array}$ & $\begin{array}{l}110^{\circ} 47^{\prime} 51.87 \\
\prime \prime\end{array}$ & 10 & $8 / 10$ & $1 / 2$ & $0.000 / 0.467$ & $\begin{array}{l}0.00000 / \\
0.00140\end{array}$ \\
\hline $\mathbf{W N}$ & Wanning, Hainnan, China & $\begin{array}{l}18^{\circ} 47^{\prime} 46.89 \\
\prime \prime\end{array}$ & $\begin{array}{l}110^{\circ} 23^{\prime} 27.86 \\
\prime \prime\end{array}$ & 13 & $9 / 11$ & $3 / 2$ & $0.639 / 0.436$ & $\begin{array}{l}0.00065 / \\
0.00131\end{array}$ \\
\hline XL & Xinglong, Hainnan, China & $18^{\circ} 44^{\prime} 4.68^{\prime \prime}$ & $\begin{array}{l}110^{\circ} 11^{\prime} 52.91 \\
\prime \prime\end{array}$ & 26 & $10 / 10$ & $2 / 2$ & $0.533 / 0.200$ & $\begin{array}{l}0.00048 / \\
0.00060\end{array}$ \\
\hline TW & Pingdong, Taiwan, China & $\begin{array}{l}21^{\circ} 59^{\prime} 23.29 \\
" \prime\end{array}$ & $120^{\circ} 44^{\prime} 21.12$ & 5 & $0 / 2$ & $0 / 1$ & $0 / 0.000$ & $\begin{array}{l}0 / 0.0000 \\
0\end{array}$ \\
\hline JP & Akita, Japan & $\begin{array}{l}39^{\circ} 51^{\prime} 26.24 \\
"\end{array}$ & $140^{\circ} 0^{\prime} 46.99^{\prime \prime}$ & 6.5 & $1 / 3$ & $1 / 1$ & $0.000 / 0.667$ & $\begin{array}{l}0.00000 / \\
0.00200\end{array}$ \\
\hline JPYD & Lzu, shizuoka, Japan & $\begin{array}{l}34^{\circ} 55^{\prime} 55.36 \\
"\end{array}$ & $\begin{array}{l}139^{\circ} 07^{\prime} 32.80 \\
"\end{array}$ & 162 & $1 / 1$ & $1 / 1$ & $0.000 / 0.000$ & $\begin{array}{l}0.00000 / \\
0.00000\end{array}$ \\
\hline KR1 & $\begin{array}{l}\text { BoryeongJangan-Beach, } \\
\text { Korea }\end{array}$ & $36^{\circ} 12^{\prime} 49.9^{\prime \prime}$ & $126^{\circ} 32^{\prime} 09.3^{\prime \prime}$ & 16 & $0 / 1$ & $0 / 1$ & $0 / 0.000$ & $\begin{array}{l}0 / 0.0000 \\
0\end{array}$ \\
\hline KR2 & $\begin{array}{l}\text { Jeollanam-do Hampyeong } \\
\text { HampyeongPort, Korea }\end{array}$ & $35^{\circ} 09^{\prime} 30.4^{\prime \prime}$ & $126^{\circ} 22^{\prime} 35.9^{\prime \prime}$ & 12 & $1 / 1$ & $1 / 1$ & $0.000 / 0.000$ & $\begin{array}{l}0.00000 / \\
0.00000\end{array}$ \\
\hline KR3 & Jeju-si, Iho-beach, Korea & $32^{\circ} 29^{\prime} 54.2^{\prime \prime}$ & $126^{\circ} 27^{\prime} 14.7^{\prime \prime}$ & 3.8 & $2 / 2$ & $1 / 1$ & $0.000 / 0.000$ & $0.00000 /$ \\
\hline
\end{tabular}


0.00000

JPCS Nago, Okinawa, Japan

$$
26^{\circ} 35^{\prime} 29.57 \quad 127^{\circ} 58^{\prime} 38.34 \quad 5.8
$$

Species level

Vitex. trifolia

3_GD Gangzhou, GuangDong, China

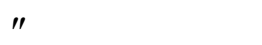

3_YN Xishuangbanna, YunNan, China

3_WC Wenchang, Hainnan, China

3_GX Longgang, Guangxi, China

Species level $22^{\circ} 0^{\prime} 38.81^{\prime \prime} \quad 100^{\circ} 47^{\prime} 49.74 \quad 555$

$"$

$19^{\circ} 32^{\prime} 42.56 \quad 110^{\circ} 47^{\prime} 51.87 \quad 10$

"

$22^{\circ} 28^{\prime} 15.35 \quad 106^{\circ} 57^{\prime} 25.94 \quad 239$
22

$3 / 3$

$1 / 1$

$9 / 8$

$10 / 11$

$7 / 8$

$7 / 8$

4

\begin{tabular}{cl} 
& 0.00000 \\
& \\
$0.000 / 0.000$ & $0.00000 /$ \\
& 0.00200 \\
$0.360 / 0.440$ & $0.00010 /$ \\
& 0.00000 \\
& \\
\hline $0.000 / 0.000$ & $0.00000 /$ \\
& 0.00000 \\
$0.639 / 0.571$ & $0.00065 /$ \\
& 0.00171 \\
$0.511 / 0.545$ & $0.00102 /$ \\
& 0.00163 \\
$0.571 / 0.536$ & $0.00051 /$ \\
& 0.00160 \\
$0.812 / 0.516$ & $0.00039 /$ \\
& 0.00000
\end{tabular}

$\mathrm{n}_{\mathrm{s}}$, the number of samples analysed; $\mathrm{n}_{\mathrm{h}}$, the number of haplotypes obsevered; $\mathrm{h}$, haplotype diversity; $\pi$, nucleotide diversity. 


\section{Table 2 (on next page)}

Variable nucleotide sites and length polymorphisms of cpDNA (trnH-psbA and trnG-trnS) sequences in the $V$. rotundifolia and $V$. trifolia, identifying 9 haplotypes (Hap1-Hap9).

All sequences are compared to the reference Hap1. "-" in sequences denote absence. 
Variable nucleotide sites and length polymorphisms of cpDNA (trnH-psbA and trnG-trnS) sequences in the $V$. rotundifolia and 2 V. trifolia, identifying 9 haplotypes (Hap1-Hap9).

\begin{tabular}{|c|c|c|c|c|c|c|c|c|c|c|c|c|c|c|c|c|c|c|c|c|c|}
\hline \multirow[t]{2}{*}{ Population } & \multirow[t]{2}{*}{ Haplotype } & \multicolumn{20}{|c|}{ cpDNA } \\
\hline & & 407 & 672 & 728 & 782 & 789 & 790 & 797 & 802 & 828 & 848 & 867 & 882 & 883 & 891 & 892 & 893 & 996 & 1008 & 1041 & 1074 \\
\hline 1_WC, DC, DL, & Hap1 & A & - & G & - & $\mathrm{T}$ & $\mathrm{C}$ & $\mathrm{T}$ & - & - & $\mathrm{C}$ & $\mathrm{T}$ & - & - & $\mathrm{T}$ & $\mathrm{T}$ & $\mathrm{T}$ & G & G & G. & $\mathrm{C}$ \\
\hline \multicolumn{22}{|l|}{ GD, HT, JPCS, } \\
\hline \multicolumn{22}{|l|}{ ZS, JPYD, KR3, } \\
\hline \multicolumn{22}{|l|}{ LYG, NJ, QD, } \\
\hline \multicolumn{22}{|l|}{ SH, TZ, WH, } \\
\hline \multicolumn{22}{|l|}{ WN, XL, XS } \\
\hline 3_GD, 3_GX, & Hap2 & . & - & . & . & G & A & . & . & . & . & - & $\mathrm{T}$ & A & . & . & . & . & . & . & - \\
\hline \multicolumn{22}{|l|}{ 3_WC } \\
\hline 3_GX, 3_WC & Hap3 & . & - & . & . & G & A & . & . & . & . & . & $\mathrm{T}$ & A & . & . & . & . & . & . & . \\
\hline 3_WC, 3_YN & Hap4 & . & - & . & . & G & A & . & . & . & . & - & . & - & - & . & . & - & . & - & - \\
\hline 3_YN & Hap5 & $\mathrm{C}$ & - & - & - & G & A & . & . & . & . & . & . & . & . & . & . & . & . & . & - \\
\hline 3_YN & Hap6 & $\mathrm{C}$ & - & . & . & G & A & . & . & . & . & . & . & . & . & . & . & . & . & . & . \\
\hline DC, DL, GD, & Hap7 & . & - & - & . & . & . & . & . & . & . & - & . & . & . & . & . & . & . & . & - \\
\hline \multicolumn{22}{|l|}{ KR2, QD, TZ, } \\
\hline \multicolumn{22}{|l|}{ WH, WN } \\
\hline $\mathbf{W N}, \mathbf{X L}, \mathbf{X M}$ & Hap8 & $\mathrm{C}$ & - & . & . & . & . & . & . & . & . & - & . & . & . & . & . & . & . & . & . \\
\hline Outgroup & Hap9 & . & A & A & $\mathrm{T}$ & G & A & A & $\mathrm{T}$ & G & A & A & . & . & A & $\mathrm{C}$ & A & $\mathrm{T}$ & A & $\mathrm{C}$ & . \\
\hline
\end{tabular}

All sequences are compared to the reference Hap1. "_" in sequences denote absence. 


\section{Table 3(on next page)}

Variable nucleotide sites and length polymorphisms of nrDNA sequences in the $V$. rotundifolia and $V$. trifolia, identifying 3 haplotypes (Hap1-Hap3).

All sequences are compared to the reference Hap1. "-" in sequences denote absence. 
1 Variable nucleotide sites and length polymorphisms of nrDNA sequences in the $V$. rotundifolia and $V$. trifolia, identifying 3

2 haplotypes (Hap1-Hap3).

\begin{tabular}{|c|c|c|c|c|c|c|c|}
\hline \multirow[t]{2}{*}{ Population } & \multirow[t]{2}{*}{ Haplotype } & \multicolumn{6}{|c|}{ cpDNA } \\
\hline & & 70 & 72 & 217 & 264 & 274 & 276 \\
\hline $\begin{array}{l}\text { 1_WC, 3_YN, 3_GX, 3_WC, DC, DL, } \\
\text { GD, HT, JP, JPCS, KR2, LYG, NJ, } \\
\text { QD, SH, TZ, ZS, WH, WN, XL, XM, } \\
\text { XS, ZS }\end{array}$ & Hap1 & $\mathrm{G}$ & $\mathrm{C}$ & $\mathrm{C}$ & - & $\mathrm{G}$ & $\mathrm{C}$ \\
\hline $\begin{array}{l}\text { 1_WC, 3_YN, 3_GX, 3_WC, 3_GD, } \\
\text { DC, DL, GD, HT, JP, JPCS, KR2, } \\
\text { LYG, NJ, QD, SH, TZ, ZS, WH, WN, } \\
\text { XL, XM, XS, ZS, KR1, KR3 }\end{array}$ & Hap2 & . & . & . & $\mathbf{C}$ & . & . \\
\hline Outgroup & Hap3 & $\mathbf{A}$ & $\mathbf{T}$ & $\mathbf{T}$ & $\mathbf{C}$ & $\mathbf{A}$ & $\mathbf{T}$ \\
\hline
\end{tabular}

All sequences are compared to the reference Hap1. "_" in sequences denote absence. 


\section{Table 4(on next page)}

Analyses of molecular variance (AMOVA) based on the cpDNA and nrDNA sequences.

Significance was tested by 1000 random permutations. $* * *, P<0.0001$. 
Analyses of molecular variance (AMOVA) based on the cpDNA and nrDNA sequences.

\begin{tabular}{|c|c|c|c|c|c|}
\hline Source of variation & df & $\begin{array}{l}\text { Sum of } \\
\text { squares }\end{array}$ & $\begin{array}{c}\text { Variance } \\
\text { components }\end{array}$ & $\begin{array}{l}\text { Percentage } \\
\text { of variation }\end{array}$ & Fixation indices \\
\hline \multicolumn{6}{|l|}{ cpDNA (all populations) } \\
\hline Among populations & 1 & 53.821 & $1.19665^{* * *}$ & 79.19 & $\mathrm{~F}_{\mathrm{ST}}=0.79195$ \\
\hline Within populations & 155 & 48.727 & $0.31437^{* * *}$ & 20.81 & \\
\hline \multicolumn{6}{|l|}{ cpDNA(species) } \\
\hline Among species & 1 & 53.821 & $1.17509^{* * *}$ & 78.25 & $\mathrm{~F}_{\mathrm{CT}}=0.78248$ \\
\hline $\begin{array}{l}\text { Among populations within } \\
\text { species }\end{array}$ & 23 & 22.242 & $0.12601^{* * *}$ & 8.39 & $\mathrm{~F}_{\mathrm{ST}}=0.86639$ \\
\hline \multicolumn{6}{|l|}{ cpDNA ( $V$. rotundifolia) } \\
\hline Among populations & 20 & 7.649 & $0.03763^{* * *}$ & 19.64 & $\mathrm{~F}_{\mathrm{ST}}=0.19640$ \\
\hline $\begin{array}{l}\text { Within populations } \\
\text { cpDNA }(\boldsymbol{V} \cdot \text { trifolia })\end{array}$ & 109 & 16.782 & $0.15396^{* * *}$ & 80.36 & \\
\hline Among populations & 3 & 14.593 & $0.72257^{* * *}$ & 63.14 & $\mathrm{~F}_{\mathrm{ST}}=0.63137$ \\
\hline Within populations & 23 & 9.703 & $0.42188^{* * *}$ & 36.86 & \\
\hline \multicolumn{6}{|l|}{ ITS (all populations) } \\
\hline Among populations & 1 & 1.075 & 0.01802 & 7.39 & $\mathrm{~F}_{\mathrm{ST}}=0.07392$ \\
\hline Within populations & 175 & 39.501 & 0.22572 & 92.61 & \\
\hline \multicolumn{6}{|l|}{ ITS (species) } \\
\hline Among species & 1 & 1.075 & 0.01524 & 6.29 & $\mathrm{~F}_{\mathrm{CT}}=0.06286$ \\
\hline $\begin{array}{l}\text { Among populations within } \\
\text { species }\end{array}$ & 25 & 7.854 & 0.01624 & 6.70 & $\mathrm{~F}_{\mathrm{ST}}=0.12983$ \\
\hline
\end{tabular}


Within populations

ITS $(V$. rotundifolia)

Among populations

Within populations

ITS ( . trifolia)

Among populations

Within populations

\begin{tabular}{ccccc}
150 & 31.647 & 0.21098 & 87.02 & $\mathrm{~F}_{\mathrm{SC}}=0.07146$ \\
22 & 7.492 & 0.02231 & 10.09 & $\mathrm{~F}_{\mathrm{ST}}=0.10091$ \\
126 & 25.045 & 0.19877 & 89.91 & \\
& & & & \\
3 & 0.362 & -0.02429 & -9.69 & $\mathrm{~F}_{\mathrm{ST}}=-0.09685$ \\
24 & 6.602 & 0.27509 & 109.69 & \\
\hline
\end{tabular}

Significance was tested by 1000 random permutations. $* * *, P<0.0001$ 


\section{Table 5 (on next page)}

Parameters of mismatch distribution Analysis of $V$. rotundifolia and $V$. trifolia based on cpDNA sequences. 
1 Parameters of mismatch distribution Analysis of $\boldsymbol{V}$. rotundifolia and $\boldsymbol{V}$. trifolia based on

2

3

\begin{tabular}{ccccccccc}
\hline & $\begin{array}{c}\text { Tajima's } \\
\text { D }\end{array}$ & P & Fu's Fs & P & SSD & P & H $_{\text {RAG }}$ & P \\
& & & & & & & \\
\hline V.trifolia & 1.8690 & 0.8820 & 0.9575 & 0.7200 & 0.0051 & 0.5000 & 0.0350 & 0.7400 \\
V.rotundifolia & -0.3997 & 0.2830 & 0.2787 & 0.4830 & 0.0049 & 0.0000 & 0.1936 & 0.4800 \\
\hline
\end{tabular}
cpDNA sequences

4 